\title{
Review of Locher, Miriam A. (2017) Reflective Writing in Medical Practice: A Linguistic Perspective, Bristol: Multilingual Matters. ISBN: 978-78309-823-1
}

\author{
Zsófia Demjén \\ UCL Centre for Applied Linguistics, University College London \\ 20 Bedford Way, London, WC1H 0AL, United Kingdom
}

For citation:

Demjén, Zsófia (2019). Review of Locher, Miriam A. (2017) Reflective Writing in Medical Practice: A Linguistic Perspective, Bristol: Multilingual Matters. ISBN: 978-78309-823-1. Russian Journal of Linguistics, 23 (4), 1115-1121. doi: 10.22363/2312-9182-2019-23-4-1115-1121.

\section{Рецензия на книгу Locher, Miriam A. (2017) 'Reflective Writing in Medical Practice: A Linguistic Perspective', Bristol: Multilingual Matters. ISBN: 978-78309-823-1}

\author{
Жофиа Дэмен \\ Лондонский университет (UCL), Центр прикладной лингвистики \\ 20 Bedford Way, London, WC1H 0AL, United Kingdom
}

Для цитирования:

Demjén, Zsófia (2019). Review of Locher, Miriam A. (2017) Reflective Writing in Medical Practice: A Linguistic Perspective, Bristol: Multilingual Matters. ISBN: 978-78309-823-1. Russian Journal of Linguistics, 23 (4), 1115-1121. doi: 10.22363/2312-9182-2019-23-4-1115-1121.

In the context of medical education, and indeed medical practice, reflective writing is perhaps not what comes to mind as a core activity. Yet an increasing number of medical schools around the world use reflective writing as part of their teaching and learning toolkit (Kind et al., 2009) and it is a core part of what is known as 'narrative medicine' (e.g. Charon 2006). Recent years have also seen a flurry of reflective writing 
published by medical professionals either as memoires (e.g. Henry Marsch's 'Do no harm', Paul Kalanithi's 'When breath becomes air', etc.) or blogs, and editorials in medical journals (e.g. the 'On being a doctor' series in the Annals of Internal Medicine). Evidence suggests that such reflection can deepen learning, improve students' and professionals' understanding of the context of medical practice (Mann 2008), and teach medical students empathetic interactions with patients (DasGupta and Charon 2004). Against this backdrop, Miriam Locher takes a mixed-method linguistic angle on reflective writing in medical education and practice and explores just what these pieces look like, what influences them and what kinds of (relational) work they might do.

'Reflective Writing in Medical Practice: A Linguistic Perspective' (2017, Multilingual Matters) reports on the linguistic analysis of an approximately 340,000-word corpus of reflective writing texts. As described in the first chapter the study is an 'eclectic' discourse analysis situated within the field of medical humanities (to which narrative medicine, mentioned above, also belongs). The focus is explicitly on texts as products, rather than processes or practices, but Locher is keen to emphasize that - in line with the linguistic tradition - they are not taken at 'face value' but are examined for what they 'do'. The overarching methodology is described as qualitative, despite the use of some corpus analysis tools and other quantification, and draws on genre analysis (Bax 2011), relational work (Locher and Watts 2005) and linguistic approaches to identity construction (e.g. Bucholtz and Hall 2005).

The data collection and analysis was conducted as part of a large multidisciplinary project, 'Life (Beyond) Writing', funded by the Swiss National Science Foundation and Chapter 2 describes the genesis of this larger study before zooming in on the linguistic branch that is the ultimate focus of the book. The data under investigation is made up of reflective writing produced by medical students at the University of Nottingham (by far the largest sub-corpus), medical students at the University of Basel (the smallest sub-corpus), and medical professionals writing for two columns in different medical journals. All texts focus on an encounter with a patient that made a particular impression on the writer. In the case of student work, this focus is built into the design and instructions of the reflective writing task, which some complete for credit. In the case of texts written by practicing physicians only texts that have this focus are included in the corpus. The reflective texts from University of Basel students are written in German, while the rest of the corpus is in English. In addition to outlining such specific details of the three corpora under investigation, and the rationale for focusing on genre, relational work and identity, this chapter also provides a very clear illustration of how the best research projects develop out of serendipities between contexts, situations, people and their interest, and, of course, the availability of funding.

The subsequent analytical chapters each answer one research question in the linguistic branch of 'Life (Beyond) Writing'.

Chapter 3 addresses the question 'What do the authors of the texts choose to write about?' Qualitative close reading of all texts by $2-3$ independent 'coders' leads to a pared-down set of 27 themes that capture what is written about throughout the corpus (e.g. communication strategies, cultural differences, history taking, emotions (the patients' and the authors'), patients being difficult, judgemental attitudes, textbook vs. 
reality, etc.). These are grouped into four clusters: 1) focus on the context of the encounter, 2) focus on the patient, 3) focus on the student or expert physician, and 4) focus on the insights gained. While this grouping helps structure the discussion, I personally found the more detailed view of the actual themes (e.g. Table 3.6) far more revealing. The clustering runs the risk of over-simplifying the range of themes, potentially making it seem like the results could be explained by the instructions the medical students were given. Of the 27 themes, the following seven appeared in more than $10 \%$ of texts across the three sub-corpora:

1) the memorability of the encounter as a result of the particular 'communication strategies' involved

2) a focus on 'student/expert emotions' involved in the encounter

3 ) the memorability of the encounter as a result of the 'patient emotions' involved

4) the illness of the patient as 'special' in some way

5) the 'impact of illness on patient's life' as a key aspect of the encounter

6) the encounter as memorable due to a special 'setting' or setting issue

7) a focus on themes 'other' than ones that occur regularly across the corpus.

Some of these themes are not surprising and this first analysis chapter contains less by way of theoretical and practical insights than others. However, this kind of work provides an essential — and interesting — handle on the nature of the data under discussion. This initial overview of themes also underpins several of the research questions answered in subsequent chapters. For example, the emphasis on 'communication strategies' even in the expert texts, which were not written for communication skills courses, suggested that these were seen as crucial beyond medical education, and that it was important to explore exactly how these were discussed in the corpus. The prominence of emotions in reflective writing texts similarly merited further discussion.

Inspired by the results of Chapter 3, Chapter 4 explores the connection between the communication skills that medical students are taught and those that become core themes of the texts. A summary list of communications skills taught at Basel and Nottingham medical schools forms the backbone of the analytical categories, or codes, in this chapter, but other skills mentioned in the texts (but not part of training) also become part of the coding scheme in a bottom-up fashion. Locher demonstrates that medical students in particular are keenly aware of the complexities of communication as they don't tend to focus on just one skill in their texts: $70 \%$ texts in the Nottingham corpus mention three or more skills, and $53 \%$ of the Basel corpus focuses on two or more skills. At the same time, students overall appear most concerned with two main skills: creating rapport or building trust and demonstrating empathy (for the Nottingham corpus these are the top concern, for the Basel corpus, they come second). These are interpersonal as opposed to transactional skills making them potentially more difficult to teach in the often artificial environment of communication skills training. The clear significance of these skills for the students motivates the research question at the heart of Chapter 6.

The inspiration for Chapter 5 of 'Reflective Writing in Medical Practice' comes partly from the larger project that the linguistic analysis is part of and provides a description of the data set in terms of genre. Specifically, Locher draws on Bax's 
(2011) cognitive approach to genre as a 'mental construct which we draw on as we create and interpret actual text' (44-45) and as guided primarily by function. The chapter begins to answer the questions 'What exactly is a 'reflective writing' text in our context? What other genres does this text type draw on?' by mapping the genres features, such as structure, layout, style, lexis, grammar (Bax 2011), of the corpus of texts. Initially, this summarises and expands on much of what previous chapters revealed about the texts but under the umbrella of genre. However, the chapter really comes into its own in the later parts of Section 5.3 and 5.4 where corpus methods are used to elucidate or elaborate on the general genre features. For example, Locher describes the grammatical composition of the texts in terms of Biber's (1988) six Dimensions and finds that the Nottingham corpus is most similar to the 'involved persuasive' text-type, while the expert corpus is most similar to 'general narrative exposition'. Similarly, the lexical composition of the texts is explored using keyword analysis. (Unfortunately, the tools used for this analysis do not cope with German, so we don't know how the Basel corpus compares.) Of course, the reflective writing tasks that student writers have to complete come with detailed instructions, which could predict (and partly do so) the responses to this chapter's research questions. Locher herself acknowledges the role of the 'assignment brief' in the findings. At the same time, a key message here is that one cannot or should not assume these things: as researchers, we should not assume that the way a task is set necessarily results in certain kinds of texts. Even in this case, where we do end up with texts that align with the instructions given and include reflection as part of narrative, writers achieve this in different ways. Some incorporate elements of the dramatic script, while others draw more on the genre of medical reports.

Chapter 6, as noted above, is inspired by the focus on interpersonal communication skills and emotion in the reflective writing texts established in Chapters 3 and 4. Drawing on the theoretical framework of relational work that Locher is so well-known for (e.g. Locher and Watts 2005, 2008), it addresses the question: 'How does the relational side of communication, as discussed in interpersonal pragmatics, surface in the texts?' 'Relational work' here refers to what individuals do to construct, maintain, reproduce and transform interpersonal relationships among each other (Locher and Watts, 2008: 96), via, for example, linguistic (im)politeness and emic judgements of behaviour as rude or polite. Understanding these processes sheds light on how medical students, in particular, recognise and develop the norms of a community of practice (e.g. Wenger 1998), i.e. how they learn to behave in particular ways in the relevant healthcare systems. By way of a case study, Locher and her team perform a close reading of 50 texts from the Nottingham corpus to identify metapragmatic comments on relational work. Examining these comments, they find that they relate to the value of rapport and empathy, the presentation of self, and the role of emotions once again, and show that these concerns tend to be intertwined. A take-home message here is that medical students demonstrate awareness early on in their training of how emotions colour all aspects of relational work (though they themselves don't put it in those terms). Armed with these results, Locher argues that medical programmes probably need to do more to help students develop strategies for handling their own as well as patients' emotions. 
With self-presentation emerging as a key concern for medical students in the previous chapter, Chapter 7 continues with the thread of relationships and relational work and focuses on identity construction and the related process of positioning. As the relational work approach implies, there is a connection between negotiating interpersonal relationships and identity construction; linguistic choices reflect and influence the relationships that interactants have or wish to create and help to position people (or indeed characters in a narrative) in relation to one another. The research questions that guide this chapter are 'What evidence of relational work that results in identity construction can we discover? How do the students deal with the tensions that might arise when having to portray oneself in a negative or positive light in the past/present?' As in Chapter 6, the emphasis is once again on students (as the second research question also indicates), but examples from all three sub-corpora are discussed.

Reflective writers across the three data sets tend to position themselves in the following 12 ways:

1) medical students (vis-à-vis patients or other doctors)

2) communication skills students (vis-à-vis tutors and conversational partners)

3) doctors (vis-à-vis patients, the patients' relatives, or nurses)

4) academic/scientist (referring to research aspects)

5) mentor/educator (referring to educational aspects)

6) business person (referring to business aspects)

7) private individual (vis-à-vis the professional self)

8) cultural individual

9) gendered individual

10) individual in the past (vis-à-vis the narrative situation)

11 ) individual in the present (vis-à-vis the narrated encounter)

12) individual projecting alternative actions in past or future (vis-à-vis what really happened)

Some of these identities clearly apply more to the expert corpus (e.g. business person, academic/scientist, mentor/educator), while others are more relevant to the student data sets (e.g. medical and communication skills student). However, almost all the texts across the three sub-corpora contrast the self across different times. This positioning of the Self in Time $\mathrm{X}$ vis-à-vis the Self in Time $\mathrm{Y}$ is a key strategy that enables students and experts to manage face in a context where they sometimes have to describe being less than ideally skilful or professional. Locher argues that these texts, which reflect the struggle to make sense of potentially contradictory identities, might be truest to the purpose of reflective writing. She recommends that the possibilities of linguistic identity construction and positioning be explicitly taught in relation to reflective writing to enhance its efficacy.

The final chapter of the book summarizes what can be learned from this study overall, both in relation to reflective writing in medicine, but also in terms of genre, interpersonal pragmatics, and linguistic identity construction. Finally, Locher (drawing on discussions with her team) returns to the idea that this study is situated within medical humanities and elaborates on how the results could inform not just reflective writing classes, but also the practice of narrative medicine. 
Overall, this is a thorough and meticulously conducted exploration of the nature of reflective writing with the processes and decisions of research discussed in rich detail. The excerpts throughout the volume are well chosen and fascinating to read. I found it a particular advantage that the study didn't just focus on English, and examples are, of course, also presented in the original language. For those familiar with Germanic contexts and settings, the examples in German yield additional colour and insights. That being said, the majority of examples and excerpts come from the Nottingham sub-corpus, which reflects its larger size, and the emphasis very clearly is on student writing, with less discussion devoted to the published texts by practicing physicians. The discussions of examples are detailed and insightful, but I would have also liked to see exactly which bits of text received what code, as most of the excerpts are used to illustrate multiple codes or findings. It might have yielded further insights to actually see the codes within the co-text of extended excerpts.

Clear structuring, frequent sign-posting, and detailed introductions and summaries make the volume easy to navigate and help readers keep the main points in mind even when the analysis chapters focus on quite distinctive aspects of the corpus. It also means that readers can more easily dip in and out of the book, as needed. Each of the analytical chapters builds on previously presented analyses, thus leading to a layering of understanding in relation to the data, while also illustrating how different analytical concepts are actually interrelated. For example, one of the findings of Chapter 3 - that students do not merely name communication skills in their reflections, but actually make them into the central themes of their texts - leads to the research question that is answered in Chapter 4: 'What is the connection between the communication skills that the students were taught and those that are mentioned in the texts?' This step by step presentation of analytical progress and research proceedings will be of particular value to newer researchers and students who benefit from seeing clearly how different analytical techniques and research questions fit and work together.

(C) Zsófia Demjén, 2019

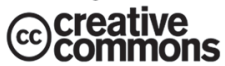

https://creativecommons.org/licenses/by/4.0/

\section{REFERENCES}

Bax, Stephen (2011). Discourse and genre: using language in context. Basingstoke; New York: Palgrave Macmillan.

Biber, Douglas (1988). Variation across Speech and Writing. Cambridge: Cambridge University Press.

Bucholtz, Mary \& Kira Hall (2005). Identity and interaction: a sociocultural linguistic approach. Discourse Studies, 7 (4-5), 585-614.

Charon, Rita (2006) Narrative Medicine: Honoring the Stories of Illness. New York: Oxford University Press.

DasGupta, Sayantani \& Rita Charon (2004). Personal Illness Narratives: Using Reflective Writing to Teach Empathy. Academic Medicine 79:4, pp. 351-356.

Kind Terry, Veronica R. Everett \& Mary Ottolini (2009). Learning to connect: Students' reflections on doctor-patient interactions. Patient Educ Couns, 75: 149-154. 
Locher, Miriam A. and Richard J. Watts (2005). Politeness theory and relational work. Journal of Politeness Research, 1, pp. 9-33.

Locher, Miriam A. \& Richard J. Watts (2008). Relational work and impoliteness: negotiating norms of linguistic behaviour. In D. Bousfield, M.A. Locher (eds.), Impoliteness in Language: Studies on its Interplay with Power in Theory and Practice. Mouton de Gruyter, Berlin, pp. 77-99.

Mann, Karen V. (2008). Reflection: understanding its influence on practice. Medical Education, 42: $449-451$.

Wenger, Étienne (1998). Communities of Practice: Learning, Meaning, and Identity. Cambridge: Cambridge University Press.

\section{Bionote:}

Dr ZSÓFIA DEMJÉN is Associate Professor of Applied Linguistics at the UCL Centre for Applied Linguistics and specialises in language and communication around illness and healthcare (humour, metaphor, narratives, impoliteness, etc.). She is author of Sylvia Plath and the Language of Affective States: Written Discourse and the Experience of Depression (2015, Bloomsbury), co-author of Metaphor, Cancer and the End of Life: A corpus-based study (2018, Routledge), editor of Applying Linguistics in Illness and Healthcare Contexts (in press, Bloomsbury), and co-editor of The Routledge Handbook of Metaphor and Language (2017), among other things.

Contact information: z.demjen@ucl.ac.uk

\section{Сведения об авторе:}

ЖОФИА ДЭМЕН имеет степень $\mathrm{PhD}$, преподает в Центре прикладной лингвистики Лондонского университета (UCL). Область ее исследований — коммуникация в сфере здравоохранения, в частности, юмор, метафора, нарративы, невежливость и др. Она автор монографии Sylvia Plath and the Language of Affective States: Written Discourse and the Experience of Depression (Сильвия Плат и язык аффективных состояний: письменный дискурс и депрессия) (2015, Bloomsbury), соавтор книги Metaphor, Cancer and the End of Life: A corpus-based study (Метафора, рак и конец жизни: корпусное исследование) (2018, Routledge), редактор книги Applying Linguistics in Illness and Healthcare Contexts (Применение лингвистики в контексте болезней и здравоохранения) (Bloomsbury, в печати)

Контактная информация: z.demjen@ucl.ac.uk 